\title{
Utilisation of coal for energy production in fuel cells
}

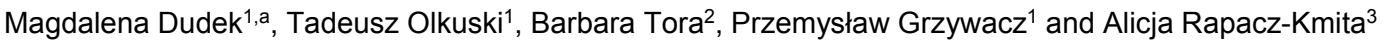 \\ ${ }^{1}$ AGH-University of Science and Technology, Faculty of Fuels and Energy 30-059 Cracow, Av. Mickiewicza 30, Poland \\ ${ }^{2}$ AGH-University of Science and Technology, Faculty of Mining and Geoengineering 30-059 Cracow, Av. Mickiewicza 30, Poland \\ ${ }^{3}$ AGH-University of Science and Technology, Faculty of Materials Science and Ceramics 30-059 Cracow, Av. Mickiewicza 30, Poland
}

\begin{abstract}
In this paper a brief characterization of fuel cell technology and its possible application in sustainable energy development was described. Special attention was paid to direct carbon fuel cell technology. The direct carbon fuel cell is an electrochemical device which directly converts the chemical energy of carbonaceous based fuel into electricity without 'flame burning'. The electrical efficiency of a DCFC is indeed very high (in practice exceeding $80 \%$ ), and the product of conversion consists of almost pure $\mathrm{CO}_{2}$, eliminating the most expensive step of sequestration: the separation of carbon from flue gases. In this paper the process of electrochemical oxidation of carbon particles on the surface of oxide electrolytes at $8 \%$ mol $\mathrm{Y}_{2} \mathrm{O}_{3}$ in $\mathrm{ZrO}_{2}(8 \mathrm{YSZ})$ as well as cermet anode Ni-8YSZ was analysed. The graphite, carbon black powders were considered as reference solid fuels for coal samples. It was found that the main factors contributing to the electrochemical reactivity of carbon particles is not only the high carbon content in samples but also structural disorder. It was found that structurally disordered carbon-based materials are the most promising solid fuels for direct carbon solid oxide fuel cells. Special impact was placed on the consideration of coal as possible solid fuels for DC-SOFC. Statistical and economic analyses show that in the coming decades, in developing countries such as China, India, and some EU countries, coal-fuelled power plants will maintain their strong position in the power sector due to their reliability and low costs as well as the large reserves of coal and lignite in the world. Coal is mined in politically stable areas, which guarantees its easy and safe purchase and transport. The impact of the physiochemical properties of raw and purified coal on the performance of the DC-SOFC was studied. An analysis of the stability of electrical parameters was performed for a DC-SOFC operating under a load over an extended period of time. The tests indicated that DC-SOFCs fed with de-ashed coal were characterized by stable operation, with a power density greater than $100 \mathrm{~mW} / \mathrm{cm}^{2}$ from a single cell.
\end{abstract}

\section{Introduction}

The power sector has been facing serious restructuring in generation technologies in many countries in the world. The economic, cultural, and technological development of societies may be impeded as a result of the growing demand for energy (particularly in rapidly developing countries such as China, India, and the countries of South America and Africa), which cannot be fully satisfied due to the depletion of fossil energy resources. Protection of the environment from pollution from emissions is also an important factor in developing new power technologies $[1,2]$. Relevant efforts have been aimed at increasing the efficiency of power generation; introducing new energy conversion technologies that impact renewable energy sources; separating and storing $\mathrm{CO}_{2}$; and developing efficient technologies for the storage, transmission, and distribution of energy (smart grids) [3, 4]. The strategy of sustainable development assumes energy production from diverse sources, not only largescale power plants but also small power generators operating on the basis of local resources and renewable energy sources. Hydrogen is also expected to play an important role in the energy economy in the future, based on environmentally clean fuel and secondary energy carriers $[5,6]$. The most important place in hydrogen technologies, as well as in sustainable energy developments overall, is reserved for fuel cells. A fuel cell (FC) is an electrochemical device which directly converts the chemical energy of fuel into electricity and waste heat. A FC can operate as long as fuel (mainly hydrogen) and an oxidant (usually oxygen taken from the air) are supplied. Although the concept of fuel cells was born early in the 19th century their rapid development began in the mid-20th century and was directly connected to the application of hydrogen as fuel[7].

Fuel cells are generally classified into two basic categories according to types of electrolyte used or temperature of operation. In the electrolyte used, five main types of fuel cells are distinguished:

a) Proton exchange membrane fuel cells -PEMFCs, operating temperature $30-80^{\circ} \mathrm{C}$,

b) Alkaline fuel cells AFCs, operating temperature 50$200^{\circ} \mathrm{C}$,

\footnotetext{
a Corresponding author: potoczek@agh.edu.pl
} 
c) Phosphoric acid fuel cells - PAFCs, operating temperature $\sim 200^{\circ} \mathrm{C}$,

d) Molten carbonate fuel cells (MCFCs, operating temperature $\sim 650^{\circ} \mathrm{C}$ ),

e) Solid oxide fuel cells (SOFCs, operating temperature $500-1000^{\circ} \mathrm{C}$ ),

Solid oxide fuel cells can be powered by not only gaseous but also liquid and solid fuels from a variety of sources, including hydrogen gas, hydrocarbons, ammonia, ethanol, synthesis gas, carbon monoxide from the Boudouard reaction, and even powdered coal [8].

Carbon-based materials are also used frequently for the construction of fuel cells, batteries, supercapacitors, and devices for analytical chemistry[9]. They can also be applied as fuel for a fuel cell. This can be done in two ways: directly and indirectly. In the first case, solid carbon fuel is introduced directly into the anode chamber (without any preliminary gasification process) of a reactor placed outside the fuel cell $[10,11]$. Direct carbon fuel cells (DCFC) have a long and uneven history. The first examples were constructed over 120 years ago by Yablochkov (1877) and Bacquerelle (1885). A carbon anode and a molten alkaline electrolyte were applied. The DCFCs operated within a temperature range of 400 $600^{\circ} \mathrm{C}$. For a long time, it was believed that carbon was not electrooxidised to $\mathrm{CO}$ or $\mathrm{CO}_{2}$ but reacted with $\mathrm{OH}^{-}$. The 1990s saw renewed interest in direct carbon fuel cell technology. The main reason for this interest in this type of electrochemical device was its several promising advantages compared to other types. Carbon-based solid fuel appears to be an attractive and abundant source of fuel for DCFCs, due to its easy storage, transport, and high level of reactivity at high operating temperatures. DCFCs can be fuelled by coal, lignite, coke, a variety of biomassorigin solid fuels, and waste carbonaceous-based materials originating from various sources. Another advantage of this type of cell is that carbon fuel and the reaction product, $\mathrm{CO}_{2}$, exist as pure substances which do not mix with each other; their chemical potentials are constant and independent of the degree of consumption (utilisation) of fuel, as well as of its distribution in the cell. This enables the cell's voltage to remain constant (at approximately 1.0 V) from the moment of the fuel's introduction to its total consumption [12].

Hydrogen gaseous fuel cells do not operate in this way. In operation, the fuel cell is consumed gradually, forming a gaseous mixture of the fuel and reaction product (steam). The gradually decreasing concentration of the gaseous fuel (hydrogen) in the mixture flowing into successive parts of the electrode causes voltage differences between different parts of the electrode.

Contrastingly, during operation of a DCFC, $\mathrm{CO}_{2}$ is produced at the anode. Thus, it isolates carbon fuel contained in the cell from the oxygen in the external atmosphere, preventing it from being oxidised in a direct chemical reaction which would produce no electricity. In this way, no carbon fuel is lost as a result of unproductive reactions in the cell. Furthermore, in contrast to coal combustion in the air, $\mathrm{CO}_{2}$, during its evolution at the anode, does not mix with the noncombustible components, mainly nitrogen. This leads to a very high concentration of $\mathrm{CO}_{2}$ in the exhaust gas stream from the cell, greatly facilitating the process of $\mathrm{CO}_{2}$ sequestration. In a case where solid carbon is used as fuel for a DCFC, the danger of explosion is incomparably lower than for hydrogen-powered fuel cells. Various types of DCFCs have been investigated recently. One of the most popular classifications is based on the kind of electrolyte used in the cell. Carbon fuel can be oxidised in an environment of alkaline, molten carbonate, or solid oxide electrolytes. The last-mentioned system, i.e. a direct carbon fuel cell with a solid oxide electrolyte (DC-SOFC), is believed to be the most promising due to its uncomplicated construction and maintenance $[13,14]$.

In a DC-SOFC $[15,16]$ carbon can be electrochemically oxidised directly to $\mathrm{CO}_{2}$ according to reaction (1):

$$
\mathrm{C}+2 \mathrm{O}^{2-} \rightarrow \mathrm{CO}_{2}+4 \mathrm{e}^{-}
$$

as well as in a sequence of reactions (2) and (3):

$$
\begin{gathered}
\mathrm{C}+\mathrm{CO}_{2} \rightarrow 2 \mathrm{CO} \\
\mathrm{CO}+\mathrm{O}^{2-} \rightarrow \mathrm{CO}_{2}+2 \mathrm{e}^{-}
\end{gathered}
$$

The Boudouard reaction (2), involving $\mathrm{CO}_{2}$ and $\mathrm{C}$ as reactants, is an additional source of the $\mathrm{CO}$ consumed in reaction (3).

On the cathode side the reduction of oxygen process took place according to reaction (4)

$$
\mathrm{O}_{2}+4 \mathrm{e}-\rightarrow 2 \mathrm{O}^{2-}
$$

The complex course of the reactions (1-3) may constitute a potential asset for this fuel cell, because it enables a choice of different design options leading to the optimisation of its performance. It should be stressed that DCFCs, just like hydrogen-oxygen SOFCs, can be designed in planar or tubular geometry. In addition, DCSOFCs can operate using a solid or a fluidised coal bed.A DC-SOFC usually operates within a temperature range of $700-900^{\circ} \mathrm{C}[12,17]$.

These electrochemical devices are expected to be applied in power generation with a rather modest power range, $10-100 \mathrm{~W}$. In the construction of such devices, the minimum electrical parameter obtained from a single cell should be not lower than $150 \mathrm{~mA} / \mathrm{cm}^{2}$, whereas the power should not be higher than $100 \mathrm{~mW} / \mathrm{cm}^{2}$. The durability and stability of the electrical parameter is also a crucial requirement for the construction of an efficient small power system [18].

The physicochemical properties of the applied solid fuels, the construction of the cell, the composition of the electrode and electrolyte materials, and the participation of $\mathrm{CO}$ produced by the Boudouard reaction (2) in the overall electrooxidation process all influence the amount of power generated by a DC-SOFC $[19,20]$.

One of the industry's main strategic efforts is the elaboration of a method of utilising coal-based fuels in solid oxide fuel cell technology. Coal is a very abundant fossil fuel around the world. Statistical and economic analyses show that in the coming decades, in developing 
countries such as China, India, and some EU countries, coal-fuelled power plants will maintain their strong position in the power sector due to their reliability and low costs and to the existence of large global reserves of coal and lignite. Coal is mined in politically stable areas, which guarantees its safe and easy purchase and transport [21-23]

The goal of this paper is to analyse the performance of solid oxide fuel cells supplied by solid powdered carbon. Special attention has been paid to the modification of the physicochemical properties of raw and purified coal using a cost-efficient method.

\section{Experimental}

One of the main criteria for the construction of efficient power sources based on direct carbon fuel cell technology is the selection of appropriate solid fuel. In this paper, two kinds of representative solid fuel were chosen for analysis. The first group consisted of carbon black and graphite powders. These materials constituted reference solid fuels for the raw and purified coal being considered as potential fuels for DC-SOFC application.

The electrochemical oxidation of carbon was studied using two types of electrochemical cells built with the support of $200-\mu \mathrm{m}$-thick commercial electrolyte discs:
(1)
(3)

$$
\begin{aligned}
& \text { C|8YSZ|LSM-GDC|LSM } \mid \mathrm{O}_{2} \\
& \mathrm{C}|\mathrm{NiYSZ}| 8 \text { YSZ } \mid \text { LSM-GDC|LSM } \mid \mathrm{O}_{2} \\
& \text { C|(Ni-Fe-Ti) 8Ce15Sm5Pr|NiYSZ|8YSZ|LSM }
\end{aligned}
$$$$
\text { GDC }|\mathrm{LSM}| \mathrm{O}_{2}
$$

where $8 \mathrm{YSZ}$ was an oxide electrolyte made of $8 \mathrm{~mol} \%$ $\mathrm{Y}_{2} \mathrm{O}_{3}$ in $\mathrm{ZrO}_{2}, \mathrm{La}_{0.8} \mathrm{Sr}_{0.2} \mathrm{MnO}_{3}(\mathrm{LSM})$ was a cathode material, LSM-GDC was a composite cathode buffer coating made of $\mathrm{LSM}+10 \mathrm{~mol} \% \mathrm{Gd}_{2} \mathrm{O}_{3}$ in $\mathrm{CeO}_{2}$ (GDC), and $\mathrm{Ni}-\mathrm{YSZ}$ was a cermetallic anode material.

In case of cell (3) the new elaborated cermet material consisted of 50 wt. $\% \mathrm{Ni}_{0.85}-\mathrm{Fe}_{0.12}-\mathrm{Ti}_{0.03}$ particles in a matrix of $\mathrm{Ce}_{0.8} \mathrm{Sm}_{0.15} \mathrm{Pr}_{0.05} \mathrm{O}_{1.9}$ was applied in DCSOFC [24]

Schematics of the two types of DC-SOFC used in the experiments are shown in Figures 1 and 2. During the experiment, argon was supplied continuously to the anodic chamber as a shield gas. The geometric area of the active electrolyte surface was ca $1.18 \mathrm{~cm}^{2}$. The electrochemical measurements were performed within a temperature range of $700-900^{\circ} \mathrm{C}$ using a potentiostat (PGSTAT 300N) equipped with GPES (CV) and FRA (EIS) modules. The experimental setup and measurement procedure were similar to those described in our previous paper [25] Ar was used as a shield gas in the anode chamber.

In order to determine the electrochemical activity of the carbon and graphite fuel, symmetrical DC-SOFCs were measured for impedance. For this purpose, a special setup was elaborated for testing solid button oxide fuel cells and other types of small FCs [26].

The concept of the electrochemical oxidation of carbon particles on an 8YSZ electrolyte (cell 1) is presented in Figure 1.

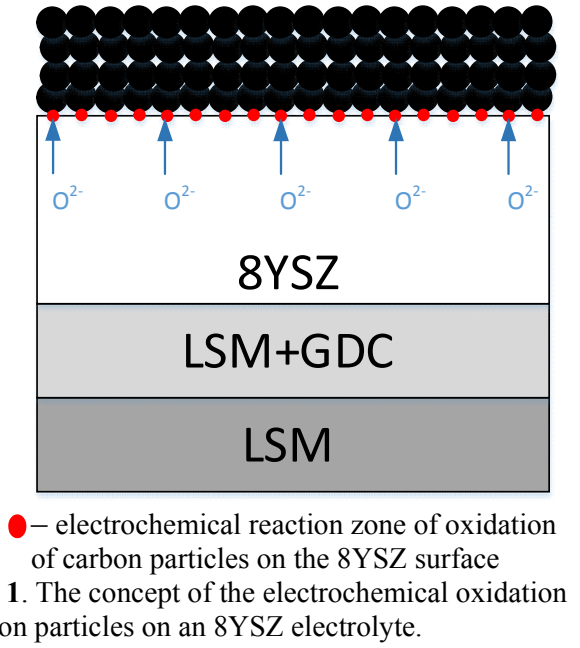

In the case depicted in Figure 1, the electrochemical oxidation of carbon particles mainly occurs according to reaction (1) $[27,28]$. The current and power generated from DC-SOFC (1) could be directly addressed to direct carbon oxidation according to reaction (1), making it easily possible to determine the activity of solid particles in the anode reaction of the direct electrochemical oxidation of fuel.

The electrochemical oxidation of carbon particles on the Ni-YSZ surface is presented in Figure 2.

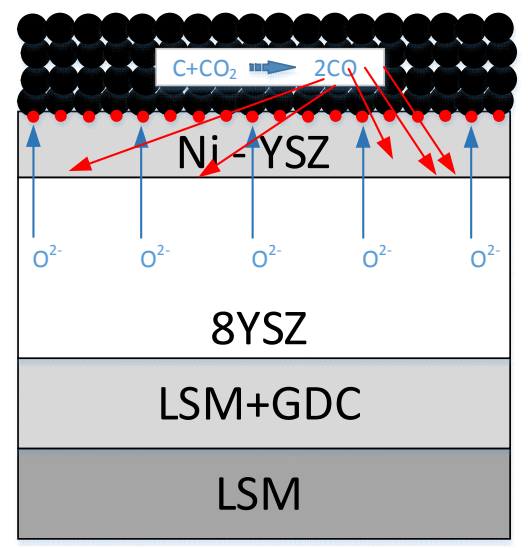

Figure 2. The concept of electrochemical oxidation of carbon particles on a Ni-YSZ anode material

In the case of cell (2) and (3), the electrochemical oxidation of carbon-based fuel could occur according to reaction (1) as well as sequences of reaction (2) and (3).

\section{Results}

In Table 1, the characteristics of graphite and carbon black powders used as reference carbon fuels for DC-SOFC studies are summarised. The data are limited to carbon content and surface area, which exert a considerable impact on electrochemical oxidation. 
Table 1. Characteristics of graphite and carbon black powders tested in the DC-SOFC

\begin{tabular}{|c|c|c|c|}
\hline $\begin{array}{l}\text { Designated } \\
\text { in this } \\
\text { paper as } \\
\end{array}$ & Type of carbon fuel & $\begin{array}{c}\text { Surface } \\
\text { area } \\
\mathrm{S}\left(\mathrm{m}^{2} / \mathrm{g}\right)\end{array}$ & $\begin{array}{l}\text { Carbon } \\
\text { content } \\
\text { (wt. \%) } \\
\end{array}$ \\
\hline $1 \mathrm{G}$ & $\begin{array}{c}\text { Timrex }{ }^{\circledR} \text { Ks } 15 \\
\text { (Imerys Graphite and } \\
\text { Carbon, Switzerland) }\end{array}$ & 12 & 98.3 \\
\hline $2 \mathrm{G}$ & $\begin{array}{c}\text { Natural graphite } \\
\text { (MS Graphite, India) }\end{array}$ & 11 & 96.8 \\
\hline $2 \mathrm{CB}$ & $\begin{array}{c}\text { Vulcan }{ }^{\circledR} \text { XC72 } \\
\text { (Cabot, USA) }\end{array}$ & 198 & 99.2 \\
\hline $3 \mathrm{CB}$ & $\begin{array}{c}\text { Ensaco } 250 \mathrm{G} \\
\text { (Imerys Graphite and } \\
\text { Carbon, Switzerland) }\end{array}$ & 67 & 98.1 \\
\hline $4 \mathrm{CB}$ & $\begin{array}{l}\text { Carbon black N220 } \\
\text { (Konimpex, Poland) }\end{array}$ & 61 & 98.3 \\
\hline
\end{tabular}

As can be seen, samples of all solid powders possessed similar carbon content.

The typical morphology of the $3 \mathrm{CB}$ sample is presented in Figure 3.

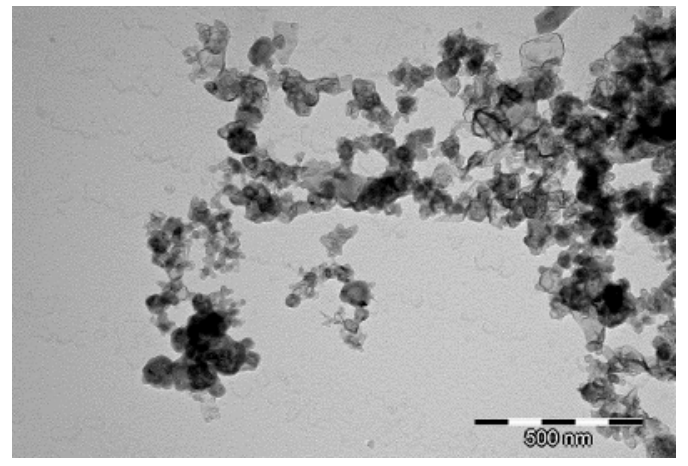

Figure 3. The SEM morphology of carbon black (3CB)

Carbon black (3CB) consisted mainly of isometric particles with dimensions ranging from $20-100 \mathrm{~nm}$. Isometric particles were observed in the case of all solid powders used to supply DC-SOFCs (1) and (2) -(3).

This is also an important feature in the electrochemical oxidation of carbon particles on the surface of an 8YSZ electrolyte. In the case of needle carbon particles, due to point contact with the surface of the oxide electrolyte an increase in polarisation resistance, and consequently very low power output, was observed $[15,19]$.

In Figure 4a, b, typical values of voltage (U) vs current density (I) and power (P) vs current density (I) are shown for a DC-SOFC (4) supplied with graphite or carbon black powders. The measurements were recorded for cell (4) at $700-900^{\circ} \mathrm{C}$.

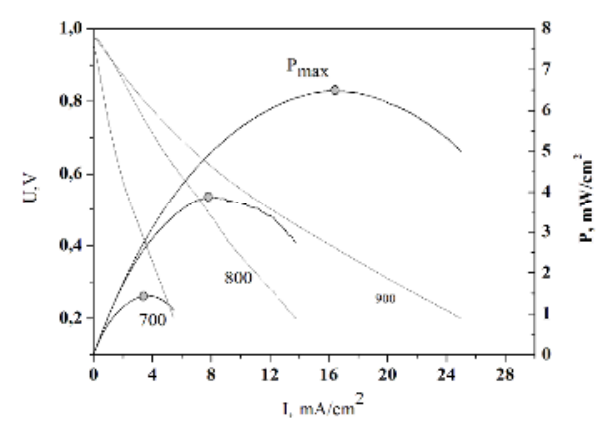

Figure 4a. U-I curves recorded for DC-SOFC (4) supplied by powder $2 \mathrm{G}$

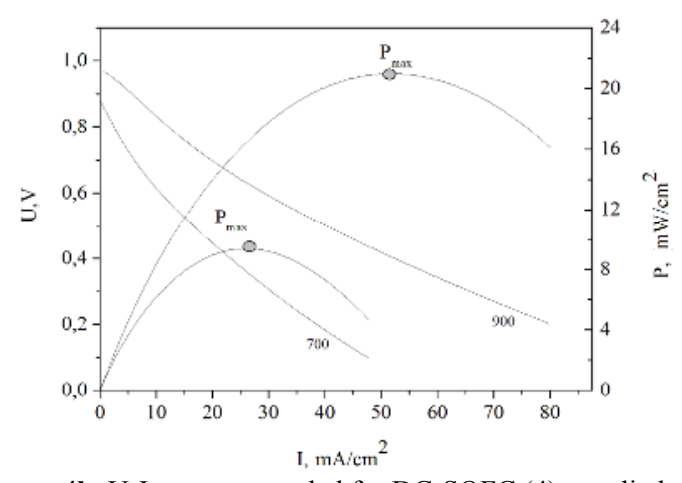

Figure 4b. U-I curves recorded for DC-SOFC (4) supplied by powder $3 \mathrm{CB}$

Based on the performed cyclic voltammetry measurements (family of U-I recorded curves), the characteristic maximum power output $P_{\max }$ of cell (1) was calculated. Table 2 presents a comparative summary of the power output $\left(\mathrm{P}_{\max }\right)$ of a DC-FC (1) supplied by graphite and carbon black powders.

Table 2. The maximum power density $\mathrm{P}_{\max }$ of DC-SOFC type (4) supplied by graphite and carbon black powders.

\begin{tabular}{|c|c|c|}
\hline Designated & \multicolumn{2}{|c|}{$\mathbf{P}_{\max }\left(\mathbf{m W} / \mathbf{c m}^{\mathbf{2}} \mathbf{)}\right.$} \\
\cline { 2 - 3 } $\begin{array}{c}\text { in this } \\
\text { paper as }\end{array}$ & $\mathbf{7 0 0}^{\circ} \mathbf{C}$ & $\mathbf{9 0 0}^{\circ} \mathbf{C}$ \\
\hline $1 \mathrm{G}$ & 0.8 & 4.1 \\
\hline $2 \mathrm{G}$ & 1.3 & 6.4 \\
\hline $2 \mathrm{CB}$ & 7.1 & 19.6 \\
\hline $3 \mathrm{CB}$ & 8.4 & 22.2 \\
\hline $4 \mathrm{CB}$ & 10.8 & 16.8 \\
\hline
\end{tabular}

As shown in Table 2, the highest power output $\mathrm{P}_{\max }$ was recorded for cell (4) supplied by carbon black powders. Graphite powders are characterised by very low electrochemical reactivity in a DC-SOFC compared to carbon black powders. These observations are in strong agreement with data presented in previous papers $[15,16,19]$.

These results were confirmed by electrochemical impedance spectroscopy measurements. In Figure 5, the typical a impedance measurement recorded for DCSOFC (1) supplied with graphite powder (2G) is presented. 


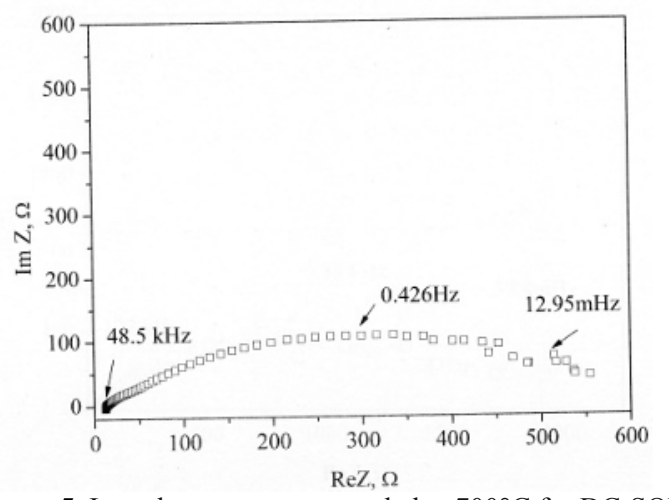

Figure 5. Impedance spectra recorded at $700^{\circ} \mathrm{C}$ for DC-SOFC (1) fed with graphite powder $(2 \mathrm{G})$

Similar impedance spectra were recorded for DCSOFC (1) supplied with other investigated solid fuels. The data measured by electrochemical impedance were simulated by the electrical circuit presented in Figure 6 .

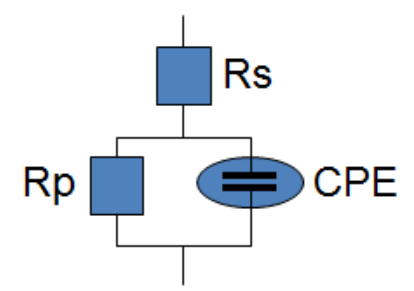

Figure 6. The electrical circuit used to fit measured electrochemical impedance data. $\mathrm{R}_{\mathrm{s}}$-ohmic resistance, $\mathrm{R}_{\mathrm{p}}$ polarization resistance, $\mathrm{CPE}$-constant phase element

The calculated values of $R_{p}$ for samples $2 G$ and $3 B$ equalled $600 \Omega(2 \mathrm{G})$ and $350 \Omega(3 \mathrm{CB})$, respectively. According to the measurements of impedance spectroscopy, the DC-SOFC cell powered directly with graphite $(2 \mathrm{G})$ powders was characterised by the highest value of $R_{p}$ resistance, which is directly connected with the slow kinetics of the anodic reaction of electrochemical oxidation of graphite particles as opposed to carbon black particles.

In this study, investigations of $8 \mathrm{YSZ}$ electrolyte chemical stability in direct contact with carbon-black-type solid fuel were performed. The experiment was conducted over two months, at $900^{\circ} \mathrm{C}$. The sample was kept in an argon gas atmosphere. No structural or microstructural changes were found on either the surface or a cross section of the $8 \mathrm{YSZ}$ electrolyte during the performed tests.

Coal, in contrast to high-purity carbon-based materials, is characterised by a number of organic and inorganic contaminants, which may have a significant impact on the process of electrochemical oxidation of carbon particles in a coal-powered DC-SOFC and thus on the values of current and power density produced by the cell $[29,30]$

There is no data concerning the impact of ash content on the process of electrochemical oxidation of coal on the surface of an $8 \mathrm{YSZ}$ electrolyte.
It is difficult to establish the level of ash that should be removed from coal to ensure high power output and durability for a DC-SOFC. In order to perform preliminary selection, certain coals were selected.

Table 3 presents the total contents of carbon, hydrogen, sulphur, ash, and volatile matter in the selected coal samples.

Table 3. Total contents of carbon, hydrogen, sulphur, ash, and volatile matter in selected coal samples, wt $\%$.

\begin{tabular}{|c|c|c|c|c|c|}
\hline $\begin{array}{c}\text { Designated } \\
\text { in this } \\
\text { paper as }\end{array}$ & $\mathbf{C}^{\mathbf{d}}$ & $\mathbf{H}^{\mathbf{d}}$ & $\mathbf{S}^{\mathbf{d}}$ & ash & $\begin{array}{c}\text { Volatile } \\
\text { matter }\end{array}$ \\
\hline $\mathrm{C} 1$ & 84.5 & 7.78 & 0.24 & 2 & 30.4 \\
\hline $\mathrm{C} 2$ & 83.1 & 4.88 & 0.33 & 3 & 29.6 \\
\hline $\mathrm{C} 3$ & 83.2 & 5.13 & 0.42 & 6 & 31.8 \\
\hline $\mathrm{C} 4$ & 64.7 & 3.31 & 0.81 & 14 & 24.7 \\
\hline $\mathrm{C} 5 \mathrm{AF}$ & 81.5 & 5.30 & 0.35 & 2 & 33.1 \\
\hline $\mathrm{C} 6 \mathrm{BF}$ & 77.4 & 4.96 & 0.54 & 8 & 28.6 \\
\hline
\end{tabular}

$\mathrm{C} 5 \mathrm{AF}$ - coal after the flotation enrichment

C6 AF - coal before the flotation enrichment

In the case of coals the total content of carbon varied between $\sim 65$ and $\sim 84 \mathrm{wt} \%$. The total sulphur level was no higher than $0.81 \mathrm{wt} \%$. All of the coal samples were grounded in an attritor mill to achieve a surface area of 10$15 \mathrm{~m}^{2} / \mathrm{g}$. In Figure 7, a representative SEM microphotograph of coal particles (1C), recorded in the course of scanning microscopy observations, is presented.

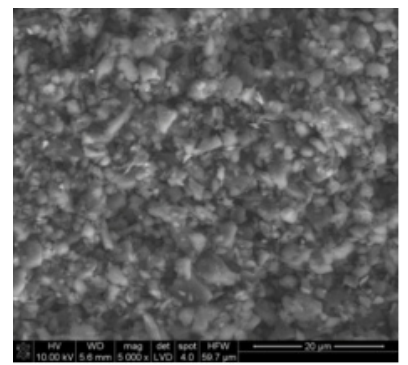

Figure 7. The SEM microphotograph of groundedcoal sample $1 \mathrm{C}$

These coal particles are characterised by particle sizes ranging from about 0.2 to about $2 \mu \mathrm{m}$. The grains are isometric, which promotes better adhesion to an $8 \mathrm{YSZ}$ surface or to Ni-YSZ anode material.

Typical voltage vs current density (U-I) and power density vs current density dependencies (P-I) (Figure 8 ) is shown for a DC-SOFC (4) supplied with C3 powder.

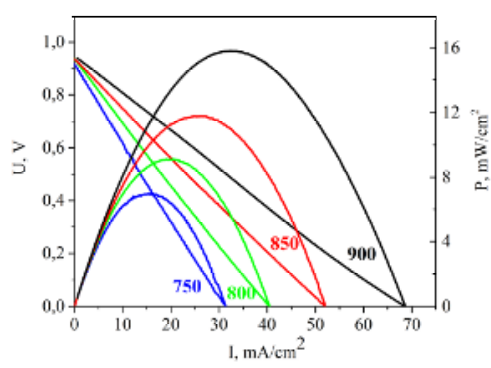

Figure 8. The family of U-I and P-I curves recorded for a DC-SOFC supplied by coal powder 3C 
An increase in current density as well as in power density vs temperature was observed for DC-SOFC (4).

Figure 9 presents the power output $\left(\mathrm{P}_{\max }\right)$ of DC-SOFC (4) vs total mineral matter content in coals used as fuel.

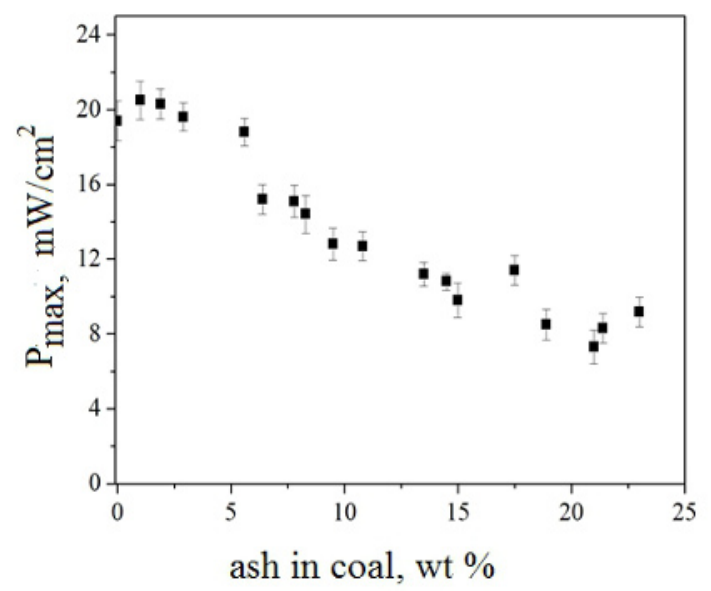

Figure 9. The impact of mineral matter in coals used as fuel on the maximum power acquired from DC-SOFC (4) at $900^{\circ} \mathrm{C}$.

On the basis of Figure 9, it can be concluded that the maximum power density $\left(\mathrm{P}_{\max }\right)$ of DC-SOFC cell (4) supplied by coals decreases slightly in the case of a solid fuel containing not more than $5 \mathrm{wt} \%$ mineral matter The presence of higher levels of impurities in the solid fuel has already been tied to the decrease of power $(\mathrm{P})$ due to the increase in the resistance of carbonaceous fuel and the consequent total resistance of DC-SOFC cell (4).

In the case of the same DC-SOFC cell supplied with purified/upgraded coal powders, the obtained values of maximum power density $\left(\mathrm{P}_{\max }\right)$ vs temperature (Figure 10) are close to those obtained for a DC-SOFC supplied with carbon black powders.

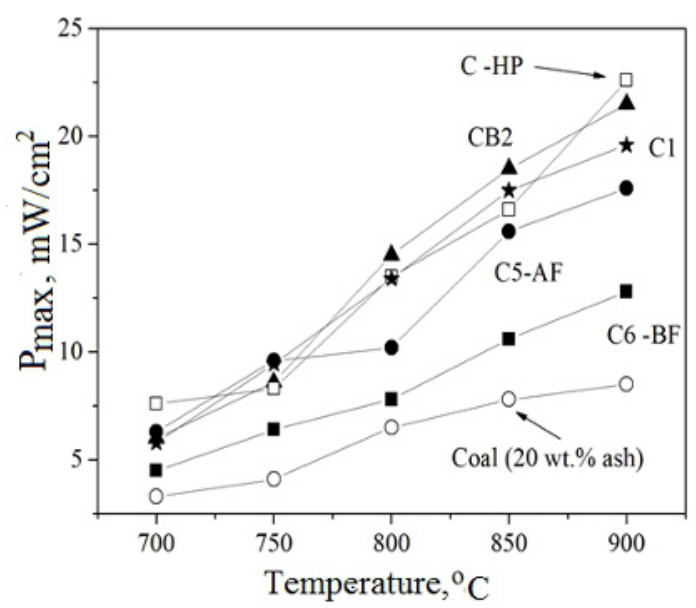

Figure 10. Dependence of the maximum power density of DCSOFC (4) fed with coal samples vs temperature.

The data for de-ashed coal (Hyper-coal, HP Japan) have also been added [31,32]
As a result of the analysis of data presented in Figure 10 , it can be stated that the highest values of $P_{\max }$ were recorded for DC-SOFC (1) supplied with upgraded coal (with ash content no higher than $5 \mathrm{wt} . \%$ ). The values are close to $\mathrm{P}_{\max }$ obtained for the same DC-SOFC (1) supplied with Hyper-coal samples [31,32] or carbon black samples (CB2).

In this graph, a direct comparison of coal before and after the flotation enrichment used as fuel is presented. An increase in $\mathrm{P}_{\max }$ from 12 to $17 \mathrm{~mW} / \mathrm{cm}^{2}$ was recorded.

The chemical stability of an 8YSZ electrolyte in direct contact with coal samples was also studied. Tests were performed at $900^{\circ} \mathrm{C}$ for 1 month.

No structural or microstructural changes were found on either the surface or a cross section of the 8YSZ electrolyte during contact with purified coals.

On the other hand, following the same experiments performed with coals involving amounts of ash greater than $10 \mathrm{wt} . \%$, some adsorption of impurities on the $8 \mathrm{YSZ}$ surface (Figure 11) as well as some mechanical cracks were observed.

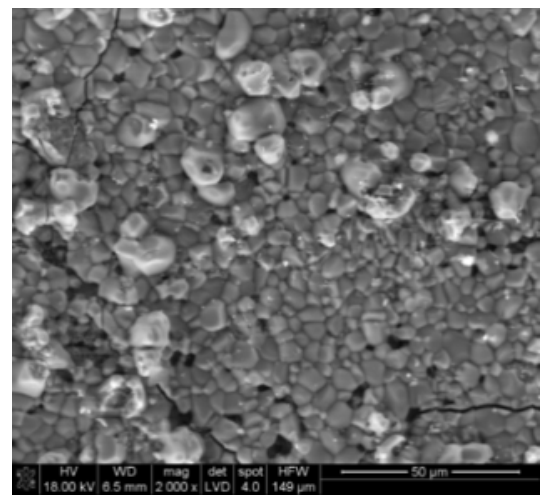

Figure 11. An SEM image recorded for 8 YSZ samples after the corrosion test.

\subsection{Electrochemical oxidation of carbon-based solid fuels on the Ni-8YSZ anode}

In the case of cell (2), carbon can be oxidised according to reaction (1) as well as in a sequence of reactions (2) and (3): $\mathrm{C}+\mathrm{CO}_{2} \rightarrow 2 \mathrm{CO}(2)$ and $\mathrm{CO}+\mathrm{O}^{2-} \rightarrow \mathrm{CO}_{2}+2 \mathrm{e}^{-}$ (3) [31]. In this section, the electrochemical performance of DC-SOFC (2) supplied with coal samples will be discussed.

Compared to DC-SOFC (1), the impact of gaseous products on the performance of DC-SOFC (2) is expected to be greater. It is also inevitable that coal samples decompose during DC-SOFC operation and release pyrolysis gases, which may affect the cell's performance and change the anode reaction pathway. Pyrolysis gases oxidise more easily than solid carbon particles on the $\mathrm{Ni}$ YSZ surface. In this case, the electrochemical oxidation of carbon particles is less significant than the gaseous fuel [33].

Figure 12 presents the typical U-I curves recorded for DC-SOFC (5) supplied with purified C1 samples. 


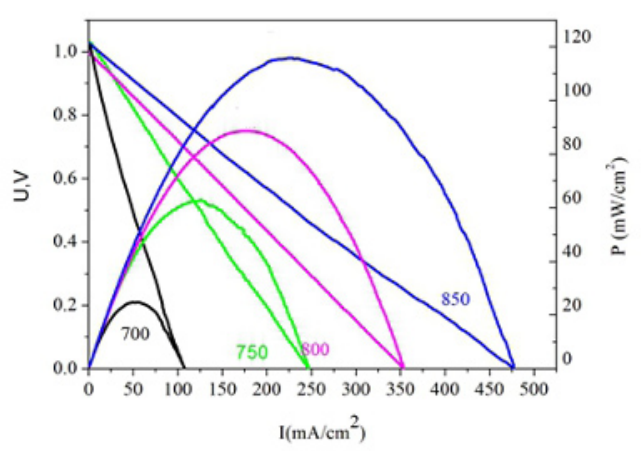

Figure 12. The family of U-I curves recorded for cell (2) supplied with $\mathrm{C} 1$ samples.

A typical increase in current density as well as power density was observed vs temperature for the DC-SOFC. In the case of the same DC-SOFC cell supplied with purified coal powders, the values of maximum power $\mathrm{P}_{\max }$ (Table 4) are higher compared to those obtained for a DC-SOFC supplied with carbon black powders, and slightly lower than those for an application of de-ashed coal (Hyper-coal).

Table 4. The maximum power density $\mathrm{P}_{\max }$ of DC-SOFC type (5) supplied by graphite, carbon and coal samples

\begin{tabular}{|c|c|c|}
\hline \multirow{2}{*}{$\begin{array}{c}\text { Designated } \\
\text { in this } \\
\text { paper as }\end{array}$} & \multicolumn{2}{|c|}{$\mathbf{P}_{\max }\left(\mathbf{m W / \mathbf { c m } ^ { 2 } )}\right.$} \\
\cline { 2 - 3 } ) & $\mathbf{7 0 0}^{\circ} \mathbf{C}$ & $\mathbf{8 5 0}^{\circ} \mathbf{C}$ \\
\hline $2 \mathrm{G}$ & 8.5 & 14.6 \\
\hline $2 \mathrm{CB}$ & 11.9 & 20.3 \\
\hline $3 \mathrm{CB}$ & 22.6 & 64.5 \\
\hline $4 \mathrm{CB}$ & 28.7 & 70.1 \\
\hline $\mathrm{C} 1$ & 22.5 & 56.4 \\
\hline $\mathrm{C} 2$ & 24.5 & 124.5 \\
\hline $\mathrm{C}-\mathrm{HP}$ & 33.6 & 105.6 \\
\hline $\mathrm{C} 5 \mathrm{AF}$ & 25.8 & 130.6 \\
\hline $\mathrm{C} 6 \mathrm{BF}$ & 17.5 & 80.6 \\
\hline
\end{tabular}

All comparable experiments were performed on the same type of cell (5) in similar conditions. However, low power output was observed in the case of the application of graphite as solid fuel. Based upon these preliminary investigations, upgraded coals seem to be adequate solid fuels for a DC-SOFC. The data existing in literature $[30,33,34]$ indicated that power output $\mathrm{P}_{\max }$ for DC-SOFC supplied by coals reached values close to $100-120 \mathrm{~mW} / \mathrm{cm}^{2}$

\subsection{The stability of an Ni-YSZ anode in a DC-SOFC operated with coal as fuel}

The most commonly used anode material in a hydrogenoxygen solid oxide fuel cell is a porous composite material, Ni-YSZ cermet, in which metallic nickel particles are distributed uniformly in a matrix of fully yttria-stabilised zirconia (8YSZ). This cermet is often applied as an anode in a DC-SOFC at this stage of developing technology. The main drawback of such material (especially nickel) seems to be low chemical stability vs carbon. This can lead to an undesirable chemical reaction between nickel and carbon, which in turn causes adverse changes in the microstructure of the cermet, as manifested in grain growth, cracks on the surface of the anode material, clogging of pores, and consequently a gradual degradation of the anode material, as well as a decline in the quality of the DCSOFC's operation. Furthermore, Ni-YSZ cermet used as a component in DC-SOFCs is characterised by limited resistance to sulphur, which is the main impurity in fossil fuels, as well as to other gaseous hydrocarbon fuels used for supplying DC-SOFCs. The problem of the application of de-ashed coal samples containing different levels of the organic form of sulphur as fuel for DC-SOFCs was presented in a previous paper [35,36].

In this paper, new an anode material $50 \mathrm{wt} \% \mathrm{Ni}_{0.85}$ $\mathrm{Fe}_{0.12}-\mathrm{Ti}_{0.03}$ particles in a matrix of $\mathrm{Ce}_{0.8} \mathrm{Sm}_{0.15} \mathrm{Pr}_{0.05} \mathrm{O}_{1.9}$ [24] with higher corrosion resistance to sulphur attack was proposed and preliminarily tested in DC-SOFC (5). The results are compared to a classic Ni-YSZ anode. The data are presented in Table 5. The coal sample $\mathrm{C} 1$ was applied as a solid fuel in DC-SOFC (5).

Table 5. The parameters of the DC-SOFC (5) during operation under voltage load with respect to the initial value

\begin{tabular}{|c|c|c|}
\hline Anode material & $\begin{array}{c}\mathbf{P}_{\max } \\
\left(\mathbf{m W} / \mathbf{c m}^{\mathbf{2}} \mathbf{)}\right. \\
\mathbf{a t ~} \mathbf{8 0 0}^{\circ} \mathbf{C}\end{array}$ & $\begin{array}{c}\text { changes in current } \\
\text { density }\left[\mathbf{I} / \mathbf{c m}^{2}\right] \text { under } \\
\text { a load of } \mathbf{U}=\mathbf{0 . 5} \mathbf{~ V} \\
\text { after } \mathbf{3 0 0} \mathbf{~} \text { with } \\
\text { reference to the initial } \\
\text { value }\end{array}$ \\
\hline $\begin{array}{c}\mathrm{Ni}_{0.85}-\mathrm{Fe}_{0.12}-\mathrm{Ti}_{0.03} \\
\text { in a matrix of } \\
\mathrm{Ce}_{0.8} \mathrm{Sm}_{0.15} \mathrm{Pr}_{0.05} \mathrm{O}_{1.9}\end{array}$ & 114 & $7 \%$ \\
\hline $\mathrm{Ni}_{\mathrm{Y} S \mathrm{YSZ}}$ & 84 & $26 \%$ \\
\hline
\end{tabular}

Based on data from the analysis presented in Table 5, it was observed that the newly-elaborated anode materials, i.e. Ni-Fe-Ti particles in a co-doped ceria solid solution, enabled us to obtain higher values of power output (Pmax) compared to classical Ni-YSZ; moreover, a DC-SOFC with this anode exhibited less variation in current density under load. This is probably related to improved chemical stability with regard to sulphur corrosion.

\section{Conclusion}

In this paper, a brief description of direct carbon solid oxide fuel cell technology was presented. It was found that carbon black powders were characterised by superior electrochemical reactivity on the surface of an 8YSZ electrolyte when compared to graphite powders. Based on the electrochemical investigation, it was found that purified coal samples (with ash content no higher than $6 \mathrm{wt} \%$ ) exhibited high values of power output, which may have been directly connected to the four-electron reaction and direct electrochemical oxidation of carbon particles to $\mathrm{CO}_{2}$. Upgraded coal samples also seem to be valuable solid fuels for a DC-SOFC with either Ni-YSZ or the newly-elaborated anode materials

$\mathrm{Ni}_{0.85}-\mathrm{Fe}_{0.12}-\mathrm{Ti}_{0.03}$ in a matrix of $\mathrm{Ce}_{0.8} \mathrm{Sm}_{0.15} \operatorname{Pr}_{0.05} \mathrm{O}_{1.9}$. The tests indicated that DC-SOFCs fed with de-ashed coal were characterised by stable operation, with a power 
density greater than $100 \mathrm{~mW} / \mathrm{cm}^{2}$ from a single cell. Improvement in the stability of electrical parameters was observed in a DC-SOFC operated with the new anode material compared to traditional Ni-YSZ.

\section{Acknowledgements}

The work was carried out under the contract no. 11.11.210.217 (AGH University of Science and Technology, Faculty of Fuels and Energy, Cracow, Poland)

\section{References}

1. D. Quiggin, R. Buswell, Energy 98, 1 (2016)

2. P.D. Lund, Energy 35, 2 (2010)

3. Ch. Karakosta, Ch. Pappas, V. Marinakis, J. Psarras, Renew. Sust. Energy Rev. 22 (2013)

4. P. Crespo, D. Granado, Z. Pang, S.W. Wallace, Appl. Energ. 170, 15 (2016)

5. A. Züttel, A. Borgschutle, L. Schlapbach, Hydrogen as a future energy carrier, Wiley-VCH (2008)

6. P. Alonso, R. Hewitt, J. Pacheco, Renew. Energ. 89 (2016)

7. R.S. Garcia, D. Weisser, Renew. Energ. 34 (2006)

8. B. Sørensen, Hydrogen and Fuel Cell Edition Academic Press (2011)

9. F.Beguin, E. Frackowiak, Cjarbons for Electrochemical Energy Storage and Conversion Systems (red.), CRC Press, USA (2010)

10. A. Dicks, J. Power Sources 156, 2 (2006)

11. S. Giddey, A. Kulkarni, C. Munnings, S.P.S. Badwal Energy 68 (2014)

12. S. Giddey, S.P. Badwal, A. Kulkarni, C. Munnings, Prog. Energy Combust. Sci. 38 (2012)

13. S. Giddey, A. Kulkarni, C. Munnings, S.P.S. Badwal, J. Power Sources 284 (2015)

14. W. Hao, X. He, Y. Mi, Appl. Energ. 135 (2014)
15. P. Desclaux, H.C. Schirmer, M. Woiton, E. Stern, M. Rzepka, Int. J. Electrochem. Sci. 8 (2013)

16. M. Dudek, P. Tomczyk, M. Skrzypkiewicz, J. Jewulski, Int. J. Electrochem. Sci. 8 (2013)

17. S. Li, A. Lee, R. Mitchell, T.M. Gür, Solid State Ionics 179 (2008)

18. P.Tomczyk, J. Power Sources 160 (2006)

19. M. Dudek, M. Sitarz, P. Tomczyk, J. Solid State Electrochem. 18 (2014)

20. K. Xu, Ch. Chen, H. Liu, Y.Tian, X. Li, H. Yao Int J Hydrogen Energ 39 (2014)

21. A. Kacprzak, R. Kobyłecki, R. Włodraczyk, Z. Bis, J. Power Sources 255 (2014)

22. V. Sarhosis, A.A. Jaya, H.R. Thomas, Energy 107 (2016)

23. C.F. You, X.C. Xu, Energy 35 (2010)

24. M.Dudek, Polish patent application P.410775

25. M. Dudek, P. Tomczyk, Catal. Today 176 (2011)

26. M. Dudek, P. Tomczyk, Chamber for testing small fuel cells, Utlity Mode PL 68129 Y1 (2015)

27. X. Yu, Y. Shi, H. Wang, N. Cai, C. Li, R.I. Tomov, J. Hanna, B.A. Glowacki, A.F. Ghoniem, J. Power Sources 243 (2013)

28. P. Desclaux, S. Nürnberger, M. Rzepka, U. Stimmin Int J Hydrogen Energ 36 (2011)

29. K. Xu K. Ch. Chen Ch, H. Liu, Y. Tian, Li H.Yao, Int J. Hydrogen Energy 39 (2014)

30. J.Jewulski, M. Skrzypkiewicz, M.Struzik, I. Lubarska-Radziejewska Int J Hydrogen Energ 36 (2011)

31. M. Dudek, P. Tomczyk, R. Socha, M. Hamaguchi, J. Hydrog. Energy 39 (2014)

32. M. Dudek, Solid State Phenomena 1 (2015)

33. A.C. Raddy, S. Giddey, A. Kulkarni, S. Badwal, S. Bhattacharya, Electrochim. Acta 143 (2014)

34. A.C. Rady, S. Giddey, A. Kulkarni, S. P.S. Badwal, S.Bhattacharya, Electrochim. Acta 178 (2015)

35. T. Chun, J.D. Mumford, T. Ramanarayanan, J Electrochem. Soc. 147 (2000)

36. S.P. Jiang, S.H. Chan, J. Mater. Sci. 39 (2004) 